MIRJANA M. STAKIĆ

UNIVERSITY OF KRAGUJEVAC

TEACHERS' TRAINING FACULTY IN UŽICE

ALEKSANDRA V. JANKOVIĆ 1

UNIVERSITY OF PRIŠTINA WITH TEMPORARY HEAD OFFICE

in Kosovska Mitrovica, Preschool Teacher TRaining College

OF APPLIED STUDIES GNJILANE WITH TEMPORARY SEAT IN BUJANOVAC

\title{
REFLECTIONS OF SOCIAL RELATIONS IN THE LANGUAGE OF ANDRIĆ'S PROSE FOR CHILDREN AND YOUNG ADULTS
}

ABSTRACT. The paper examines the language of Andrić's prose on the example of his short stories "Deca" (Children), "Kula" (Tower), and "Prozor" (Window) written for children and young adults, interpreting social relations which represent their thematic, sociological, cultural, and historical context. We studied causes of social prejudices which represent the main cause of interpersonal and internal conflicts of the main protagonists in the context of learning sociological theories (sociocognitive theory, theory of social identity, and theory of social learning) and from the standpoint of the psycholinguistic approach. We also observed language as a medium in discovering the internal and external characterization of protagonists achieved by means of verbalization of internal and external conflicts. We interpreted social relations and conflicts reflected in the language as an aesthetic, cultural, and social phenomenon as the conceptual framework of Andrić's prose. Literary language thus becomes a medium that achieves a cognitive role, in addition to its aesthetic role, discovering and illuminating social relations and conflicts which represent a reflexive core woven into the conceptual framework of the three short stories for children and young adults: "Deca" (Children), "Kula" (Tower), and "Prozor" (Window).

1 mirjanastakic073@gmail.com ; aleksandra.j78@gmail.com

This paper was submitted on August 16, 2017 and accepted for publication at the meeting of the Editorial Board held on September 19, 2017. 
KEYWORDS: literary language, psycholinguistic approach, Andrić's prose for children and young adults, social relations, conflicts.

\section{INTRODUCTORY CONSIDERATIONS}

Short stories "Deca" (Children), "Kula" (Tower), and "Prozor" (Window) by Ivo Andrić belong to literature for children and young adults according to the criteria of genre classification. Theorists of literature for children suggest that child's nature best responds to cheerful and humorous content, emphasizing its "vitalistic approach" to life and its phenomena, although "life imposes dark tones as well, but the author strives to alleviate them, avoiding traumatic scenes" (Marjanović, 2009, p. 29). It is the deeply rooted attitude mentioned that "literary works for children and young adults do not tolerate dark scenes from reality" (Stakić, 2014, p. 246). The aforementioned short stories written by Andrić shatter the illusion of childhood as the happiest period in a person's life and reveal that children "also have pains and long sufferings of their own" (Андрић, 1963, р. 52), that many remembered events from the period of growing up actually represent traumas with serious consequences on the individual's personality, so Milinković believes that Andrić's short stories can be called "stories for children only conditionally" and asks: "did Andrić write children's stories at all, or was he simply inspired by certain childhood events while writing for adults" (Милинковић, 2014, p. 208). What qualifies these stories as stories for children and young adults are their childhood-related topics and the fact that the protagonists are children. The thematic core of all three short stories develops from child's play, but not from the innocent kind, instead, as Andrić himself states, "from an odd and often cruel play" (Андрић, 1963, p. 47), which reflects a complex world of social, cultural and historical relationships that make the social context of Andrić's prose, allowing us to examine the causes of social prejudice reflected therein from the standpoint of sociological and psychological theories. Literary language thus becomes a medium which achieves a cognitive role, in addition to its aesthetic role. Expressive power of his style reveals the hidden sociological and psychological causes of interpersonal and inner conflicts of the protagonists and reflexive layers that represent the ideological concept of Andrić's prose. 


\section{REFLECTIONS OF SOCIAL RELATIONS IN THE LANGUAGE OF ANDRIĆ'S SHORT STORIES}

The titular lexeme of the short story "Deca" (Children) is associated with harmlessness and naiveté of the children's world. However, the illusion of protection of the childhood world is shattered at the very beginning. Andrić inserted a narrative within a narrative to underline the importance of events belonging to the thematic core of the story. The story begins in the first person, when a nameless narrator addresses the reader with a single sentence, stating that his friend, a silver-haired engineer shared with him a childhood memory one evening. The memory is recalled straight away in the form of direct speech. Inserting a narrative within a narrative and recalling memories from the first person perspective, in addition to giving the story a sense of credibility, suggestiveness, and emotion, emphasizes the importance of the event from the memory, because it is worthy of the story conveyed by the narrator. The emotional and psychological expressiveness of the memory is also shown by the age of the protagonist to whom the narrator lends his role. The adjective silver-haired indicates that he is a mature man and also serves to underline the uniqueness of the remembered event. It is a lasting memory that escaped oblivion, a memory of a childhood game, which shatters the illusion of childhood as a period of harmlessness and naiveté at the very beginning of the story. The protagonist calls children little people who invent odd and cruel games. Epithets odd and cruel semantically and directly define the noun games only at first glance. Odd games, meaning a different perspective, i.e. perception that differentiates the child's perception of the world from the rational understanding of an adult is a qualifier of the child and his games, in which the dominance of imagination assigns a qualifier odd to rational perception. However, the epithet that describes children's games as cruel links the world of childhood to the adult world in which cruelty is, unfortunately, very common.

The memory of games begins with a general description of war games which the children from the narrator's street waged against children from the neighborhood, only to stray into a detailed description of a cruel variation. The game would turn into a penal expedition in which the children from the narrator's street would go to beat up Jewish boys living in the Jewish quarter during reli- 
gious holidays. One spring evening, leaders of the gang, Mile and Palika, invited the narrator to join them, and the grey-haired engineer describes his memory of the event in the following words: "I, who has never taken part in any such endeavor, felt greatly honored by the two leaders" (Андрић, 1963, p. 48). In the context of social relations reflected in the literary language of Andrić's short story, three lexemes are marked in the quoted sentence: endeavor, honor and leaders. They are semantically related: endeavor earns the honor and praise from the leader, a leader is someone who has become famous through his endeavors and becomes the subject of praise. Their meaning in the depicted structure of the presented situation is opposed to their true meaning. An endeavor that involves beating others involves no heroism. Such an action should not be rewarded but punished, therefore individuals who practice and encourage such behavior are tragically lacking in qualities that make a true leader. The question we should ask here refers to social influence on the distorted perception of values in Andrić's child protagonists. The short story doesn't include any specific timeframe or period indicator based on which we could pinpoint it. The fact that boys frequent "Jewish quarters" indicates the segregation of Jews, based on which we can place the story in the period prior to WWII. This localization is further confirmed by the mention of religious holidays. In the post-war Socialist Federal Republic of Yugoslavia, it was not allowed to publicly celebrate religious holidays, so this attribute indirectly guides us to place the short story in the first third of the $20^{\text {th }}$ century. Social influence on boys' attitudes and values is also confirmed by the adverb in the sentence that describes the place where the boys made an ambush for the Jewish boys: "We went down the street where we usually had brawls with Jewish boys" (Андрић, 1963, p. 48). The adverb usually reveals that this is a common practice, not unusual or rare, but quite typical. The question is - what could be the cause for violence that one group of children practices against another.

The socio-historical context of this question is contained in the presented fact that Jewish children are victims of violence. Ever since the Middle-Ages, Jewish people, as a religious and ethnic group have suffered the consequences of prejudice, intolerance, and hatred which escalated in the mid- $20^{\text {th }}$ century when about $6,000,000$ Jews were killed in the Nazi-orchestrated genocide (Greif, 2009). However, agents of anti-Semitism in the story are not adults, but children, "little people", so we can explain the prejudice they 
nurture in accordance with numerous psychological and sociological theories. They state that prejudices define an individual's attitudes toward important social issues shaped by the dominance of the irrational part of the attitude's affective component, which is illustrated in one's attachment to the projection of aggression, desire for domination, and narcissism (Dimoski, 2011). According to the theory of social identity, prejudices are created if there is a strong identification of a child with their social group, if that group already nurtures prejudices, in other words, the emergence of prejudices requires the connection between an individual and society (Nesdale, 1999, 2004). According to Tajfel and Turner, every person is a member of one social group or another, and if their affiliation with the group is strong, the individual will perceive the members of his/her group as close, whereas members of other social groups will be perceived as foreign and different (Tajfel and Turner, 1979). The presence of prejudice in one's group or the desire to emphasize the superiority of one's own group leads to the labeling of others as bad (Томашић, 2011). This is a crude distortion of reality, which is further confirmed by the strong connection between prejudices and deep rooted stereotypes (Gidens, 2003). Theory of social identity can explain the irrational feeling of superiority of the Nazis in Germany, the consequence of which was anti-Semitism and the passing of the Nuremberg laws in 1939 that legalized the persecution of Jews (Milgram, 1999). Abraham explains the delusion of grandeur of some nations by the fact that every nation is founded on the myth and identifies with the main hero, stating that "this is remarkably similar to deranged ideas on the origin of mental patients" (Абрахам, 1999, p. 47). Socio-cognitive theory, founded by Aboud (Aboud, 1988) explains the development of prejudice in children as a consequence impacted by social factors. However, this theory doesn't neglect the impact of cognitive processes either, underlining that the prejudices are strongest in children aged 7 , which is when a child learns about the characteristics of the group he/she belongs to (Oppenheimer and Midzic, 2011). Dimoski indicates that prejudices are attitudes brought to extreme and that they comprise three components: cognitive, conative, and emotional, underlining the influence of the emotional component, because "the resistance of one's attitudes to changes, intensity of their expression, and tendency to ignore the other two aspects of the attitude" depend on its intensity and quality (Dimoski, 2012, p. 606). The impact of the emotional component on the behavior of 
Andrićs protagonists is shown by the sentence the leaders use to approach children, inviting them to join: "Are you my friend?" (Андрић, 1963, p. 47). Its interrogative intonation is just a pretense, because it actually has the role of a psychological imperative: Prove you are my friend!

Emotions and social attitudes and relations are reflected in children's behavior. Andrićs protagonists mimic the adopted behavioral pattern in a game, which is not really a game, but a brutal and cruel hint of conflicts and harsh war times to come. Verbal attitudes become a deed, an act of violence from which the pretense of children's play seemingly eliminates seriousness and consequences left by every act of destruction and aggression. The narrator of the short story "Deca" (Children), although accepting the game with enthusiasm at first, when he is face to face with a Jewish boy he is expected to hit, remains motionless. His repudiation of violence is symbolically hinted at in the hidden meaning of an expressive image of the comparison used to describe the agitation of Jewish boys. The narrator compares them with does in a forest glen. The comparison indicates the exposure to danger, but its hidden layers of meaning also point out to the innocence of the victim. Innocence of the victim is implicitly repeated through a comparison at the end of the story. The story ends with a dream in which the childhood event that causes a trauma is repeated. The narrator dreams that a Jewish boy with a face of a martyr is running past, "light on his feet and unstoppable as an angel" (??????, 1963, p. 54), whereas he, like many years before, let him pass without hitting him, although he well knows what the consequences will be. The dream occurs in another variation of the traumatic event. The boy stands in the street alone and covered in spit, under relentless afternoon light, and the time stands still as well, while his comrades are departing. In the described event, the purpose of personifying time (it stands still) and light (it is relentless) is to indicate the duration of the traumatic event in the subconscious of the boy and to intensify the sense of shame due to public humiliation. Psychoanalysts believe that in dreams, the individual goes back to the earliest events, hidden desires or fears and becomes a child again in his mind and feelings. In sleep, the entire psychological activity and the resistance with which the dominant psychic force opposes the suppressed forces gives in. According to Freud, the main mechanisms of fantastic representation in dreams, or the "mechanism of dream work" are: condensation and displace- 
ment (Freud, 1964, p. 28). Through condensation, two different thoughts are combined and amalgamated into a single, multifaceted thought, whereas displacement is the result of censorship of dreams. In displacement, a latent element is substituted with an allusion, thus displacing psychic emphasis from one major element to another, less important, which makes it look as if the dream had shifted its focus. At first glance, the narrator's dreams are devoid of censorship and focus on displacement, reflecting only the condensation of meaning. We already said that the comparison with an angel indicates the innocence of the victim. The epithet that describes the face of the Jewish boy as martyr-like has the same function. The aforementioned figures of speech emphasize the condemnation of aggression. Displacement of meaning is also indicated by the personification of time and light which underlines the duration of the traumatic event in the subconscious mind. However, dream censorship is also present, hiding the path from the allusion to the actual element of the traumatic event. In the narrator's dream, the censorship refers to inner tension and dualistic definition of the sense of guilt and shame. These feelings are not a consequence of public humiliation and shame, because his friends spat at him in the middle of the street, ${ }^{2}$ but rather a consequence of internal condemnation for taking part in such an act. According to Syentmarton, a man cannot escape "the condemnation of his own conscience" (Syentmarton, 1990, p. 184), the consequence of which is the sense of guilt (Миливојевић, 1993).

Interpersonal conflict between different groups turned into an intergroup conflict, in which the narrator was characterized as weak, unworthy, a coward, and a traitor. This shook his personal sense of security, because belonging to a group is what gives an individual social identity. The loss of social identity causes a personal inner conflict: how to win a place in the group, if it requires not just external, but internal aggression as well, behavior opposed to the nature and feelings of man. ${ }^{3}$ The hero of another Andrić's short story "Prozor" (Window) has a similar dilemma. He is also a narrator who recalls a traumatic event from early childhood. A friend of the narrator, Miško, asked the narrator to break the windows on an old lady's house. The boy refuses to "participate

2 In the depicted world of the story, narrator's decision is considered betrayal by the rules of his comrades. A direct consequence of such an act is not only an exclamation used to chase cattle away: „Git!” (Андрић, 1963, p. 52), but spitting in his face, mockery, derision, and contempt of the whole group, as well. 
in the game", which causes double punishment: 1) because he refused to participate in the game, the friend broke his windows, 2) his father gave him a vicious beating because of the broken window. Narrator's refusal to participate in the endeavor is motivated by numerous reasons, and the common denominator is fear. The boy fears punishment, because the old lady will tell their parents, the teacher, and the police what they had done, and he is afraid of all that, especially his father's beating. In addition, there is also internal moral control, because although he doesn't like the elderly neighbor, breaking her windows seems too severe a punishment.

In the short story "Prozor" (Window), social relations are presented on three interpersonal levels: 1) social community and an ostracized individual within it; 2) a group and a child who breaks the rules enforced by the leader; 3) patrocentrism and domination of the father in relation to other family members.

The ostracized individual in the depicted community of the Andrić's short story is the old lady whose windows the boys wanted to break. She is ostracized and shunned by the entire community and children's attitude only reflects the attitude of the adults. The narrator says "he had a feeling no one liked her" (Андрић, 1963, p. 55), describes her as an "unsociable and meddlesome hag" (Андрић, 1963, p. 55) and describes her isolated house as "reminiscent of a witch cottage from fairy tales" (Андрић, 1963, p. 55). Children's aversion is partly rationally explained, the old lady was a menace for the neighborhood, especially harsh on children who played under her windows or around her garden. However, the true reasons for shunning the old lady cannot be rationally explained and their causes are deeply rooted in superstition and prejudice. One of the signs that prejudice exists is the refusal of contact with "the others", ostracism, avoidance, mockery, "hate speech" or even physical attacks (Маричић, 2009).

3 Andrić describes it as follows:

„Days have passed and I couldn't stop thinking about and dwelling on my humiliation. My entire childhood world has crumbled, and lay at my feet in pieces. I stood above it, failing to understand anything and knowing only one thing: that I suffered. I stood there and didn't know where to disappear and hide under the sky, so humiliated, embarrassed and alone. How should I behave toward Milo, Palika and others when all I want is to be their equal, but I cannot, and how should I behave toward Jewish boys who should be attacked and beaten it seems, and I don't want that" (Andrić, 1963, p. 53). 
„In our small world, on the steep slopes of Sarajevo suburbs, a woman living alone, through no guilt of her own, was watched with mistrust and wariness, superstitiously assuming that it must be a wretched creature that cannot bring joy to herself or others. Something $f$ that superstition floated around the old lady's house, condensing into an atmosphere of vague fear and dull enmity. With her mistrust and harshness toward people, the old lady only reinforced such feelings in these poor and ignorant people" (Андрић, 1963, p. 56).

In the quoted passage, epithets that define fear as vague and enmity (feeling similar to hatred only less intense) as dull, reveal a psychological layering of feelings stemming from superstitious assumptions. A man is afraid of everything that threatens his security. Rational fears are justified, but even irrational fears, like the fear that there are people who bring misfortune, require a logical explanation. Psychological ambiguity of the causes of fear and its vagueness, as well as the description of the old lady's house as reminiscent of a witch cottage, shows that this is a reflection of the pagan fear of witches. ${ }^{4}$ What distinguishes the old lady from the rest in her social community is not her character, or her appearance - it's the fact that she lives alone. Andrić uses different lexical variations to emphasize this fact: 1 ) she lives alone; 2) her house is isolated; 3) he describes her as an unsociable hag; 4) there is a statement that a woman living alone brings misfortune. Her isolation from the community, both social and physical, is the cause of prejudices about a wretched created that brings misfortune. This „superstitious assumption" (Андрић, 1963, р. 53) did not arise among children who still retain their belief in the magical world of fairy tales, populated with fairies, witches, and wizards, but among adult members of the community, which is explained by the lack of self-awareness of a modern man by Jung. Criticizing crowd mentality, he underlines that by condemning others, we unconsciously reveal our own defects, i.e. projecting our own unrecognized mistakes on others (Jung, 1984). The atmosphere of vague fear of the old lady is actually built on the subjective fear of solitude shared by all community members. This community is described as ignorant and poor by Andrić; in addition, the research from the

4 Veselin Čajkanović wrote about the widespread belief in the existence of witches among the Serbian people (Чајкановић, 1994), and Vladimir Bajer points out to recorded cases of brutal punishment of women who were accused of witchcraft (banishment, persecution, and even murder) (Bajer, 1969). 
1980s shows that individuals from lower social strata, or those whose status has declined, are more prone to manifesting prejudice than those who belong to higher social classes, or whose status is improving (Reik and Adcock, 1978).

In the depicted social community, fear is disguised and shaped into a prejudice directed toward the isolated member of the community, and as such, transformed into rejection and silent condemnation transferred to kids. Transfer of prejudice from adults to children is explained by the theory of social learning. Allport explains the causes of prejudices in children by the fact that children acquire prejudices by observing the behavior of adults around them and imitating that behavior (Allport, 1954). In the period when children start to ask questions, answers to those questions commonly include prejudices and stereotypes of the adults. In the absence of information or knowledge about others, or based on a deep rooted stereotype, adults form opinions and convey them to children. In turn, children, either via direct training, observation or mimicking the verbal and non-verbal behavior of parents and adults adopt their attitudes toward members of a specific group, which causes reliance on "simple and inaccurate beliefs" (Aronson, Wilson, Akert, 2010, p. 434).

The narrator's relationship with his father is marred by fear: "Father's presence lay on us like a burden, dark shadow, and constant feeling of unease and fear with which we paid every meal" (Андрић, 1963, р. 57). The lexemes burden and shadow that underline the weight of father's presence and reinforce the feeling of fear and unease are used metaphorically here. They indirectly contribute to the characterization of the father whose traits we learn about from the narrator's memory. The narrator describes him as $a$ strict and vicious father, embittered man, never going into details of father's behavior, his silence, and avoidance of eye contact which he used to torture members of his family during family dinners. The causes of the narrator's fear are not irrational. They culminate in the brutal scene of beating because of the broken window, metaphorically described by Andrić as an "obscure game, painful beyond endurance" (Андрић, 1963, р. 59). The noun game thus becomes a symbol of everything it actually isn't: brutal distortion of reality, its displacement into a harsh domain where participants in the game violate ethical norms of behavior and rules of humanity. Maybe calling such behavior a game is a self-defense mechanism which ought to protect an individual from brutality: things that 
occur are not real and cannot really hurt him. The psychoanalyst Karen Horney indicates that in the psychic life of an individual, others regularly appear as models, subjects, helpers or opponents, which makes individual psychology equal to social psychology and vice versa. She believes that the archetypal cause of fear in children lies in the absence of love and warmth during childhood, and the original hostility that bears all future conflicts is created from this fear (Хорнај, 1965). We find the same thought, only expressed in literary language, in Andrić's story "Prozor" (Window). He says: "All our life, we are trying to cure ourselves of childhood" (Андрић, 1963, p. 60).

The act of window breaking represents revenge for the narrator's refusal to participate in the breaking of the old lady's windows. This act reflects the relationship between a group and a member who refused to follow the rules defined by the leader. The boy who organized the quest of window breaking is described by the narrator as "small and unsightly, but courageous and daring" (Андрић, 1963, р. 55). The aforementioned description contains four epithets, two in each pair, connected with a coordinating conjunction but. The conjunction but indicates a semantic contrast of the epithets, a small and unsightly individual is not expected to be courageous and daring. The next description also involves a contrast: "Miško is a person with erratic displays of wickedness and kindness". His behavior, although in contrast with his appearance, helps him establish dominance in the group, and although he is younger than the narrator, he is the de facto leader who plans and designs all the gang's quests and activities. Courage and daring are dominant in relation to physical characteristics, whereas unpredictability and explosiveness in behavior indicate the desire for domination. Position of the leader and authority make up for other physical defects, but to maintain that position, one needs to subjugate other members, either through fear or admiration.

The punishment mechanism described in the Andrić's short story "Prozor" (Window) is depicted from a distorted ethical perspective. The boy is punished twice for something he didn't do. In reality, there is no guilt, but the narrator's refusal to participate in the activity of window breaking is not motivated by moral reasons, but by fear of the act. The very knowledge that the windows will be broken nonetheless and that he failed to dissuade others from participating out of fear makes him an accomplice. In real life, fear is also the primary cause of inaction and unconscious 
guilt. Fromm and Suzuki (Fromm \& Suzuki) point out that the conscious and unconscious in an individual are socially conditioned. They depend on the structure of a society and the patterns of feelings and opinions it shapes. In order to survive, human society has to model the character of its members, so that "an individual cannot afford to harbor feelings and thoughts that do not match the patterns of his culture, instead, he is forced to suppress them" (Фром и Сузуки, 1977, р. 227). Suppression is masked by the willing pretense that a person wants to do things he is actually forced to do, because a different behavior would produce some form of social condemnation or punishment.

The short story "Kula" (Tower) also indicates the impact of family and society in creating prejudices. The story is told from the third-person perspective, by an omniscient narrator, who uses a tower, in reality an old Ottoman gunpowder warehouse, to tell a story about the childhood of his main hero, the boy Lazar. Same as in the stories "Deca" (Children) and "Prozor" (Window), here we also have the memories of a mature man. There are three units, actually three fragments of memory of the tower in the narrative, and each of them contains a memory of a traumatic event which is somehow associated with the tower.

The first fragment is a memory of painful punches the boy received while playing. Here we also have a war game in which children are divided into "us and them", i.e. "Serbs and Turks" (Андрић, 1963, p. 10). This division illustrates the social context of the children's game and its connection to historical events. The division is not made by ethnic group, instead members of the same group divide themselves in two groups, so their punches are "gentle and symbolic", but in contrast, "exaltation and glory are genuine" (Андрић, 1963, p. 11). In this game, which represented a "magical and innocent battle" for Lazar, someone punched the boy's fingers "viciously hard". Physical pain soon turns into psychological pain. The boy now has a sense of real war and real enemy who hits without mercy. He feels stunned, cheated, and disgusted. The second fragment is related to fear. Lazar is passing through the tower's courtyard on his own. There are no playmates, games, racing. He feels that he is in a strange and unknown world, far from everything that is familiar. The sense of fear is described as groundless and overwhelming. The third fragment is related to the sense of awkwardness and fear, when a girl strayed into the tower. All these memories are connected by game, fear, and pain, 
but they also symbolically show the path to inner maturation of an individual, as well as temptations and obstacles that follow him on this path.

We will examine the third fragment of memory in terms of reflection of social relations, when a girl Smiljka strayed into the tower. The narrator says that girls never took part in the games within and around the tower, so Smiljka's unexpected appearance was like seeing a "creature from another world" (Андрић, 1963, p. 14). The main layer of meaning of this comparison emphasizes the factor of surprise, the appearance of a girl surprised and confused the boys; however, in the hidden layers of meaning, this comparison indicates a sharp separation of the patriarchal society to men and women. In the period of primary socialization which begins in the early childhood (Hofstede, Hofstede, Minkov, 2010), a child in a patriarchal society is faced with numerous stereotypes that underline the subordinate role of women. Even in literary works read, sung or told to children (lullabies, fairy tales, etc.), women are subordinate: they are weak, helpless and look to men for help. Svirčev interprets the reducing of women to instability and fragility as the patriarchate's alibi for repressive control of women (Svirčev, 2010, p. 67). Trebješanin explains the endurance of such attitudes in modern society by the very traits of prejudices, which aren't based on actual experience or rational arguments, rather, they are contaminated by affect and extreme resistance to changes (Trebješanin, 2008).

The hero remembers when the girl is approached by the boy Đordije, the oldest and strongest among the boys. This moment is described with a comparison that Đordije pounced on her "like a sparrow hawk swooping on a chicken" (Андрић, 1963, p. 14). This comparison doesn't only reveal the author's deeply-rooted connection with folk tradition and lexicon, but it also reflects the psychological relationship between the victim and her pursuer. The narrator has mixed feelings, which is why he displays an unconscious reaction in the manifestation of the prejudice. Đorđije whom he never liked, seems even more repulsive in those moments, but he also appears much older and bigger, "majestic, worthy of sympathy and admiration somehow" (Андрић, 1963, p. 15). The contrast in the descriptions shows that "in his emotional reactions to social phenomena, an individual doesn't have to react harmoniously and agreeably in emotional terms, instead, his reactions can be characterized by ambivalence" (Dimoski, 2012, p. 606). 
When the mother of the girl appears among the boys and scolds them, they feel fear and shame, and Đorđije "retreats slowly, like being awoken from a dream and murmurs something incomprehensible" (Андрић, 1963, p. 16). The comparison with being awoken from a dream implies an unconscious component of behavior. The moment of reality in which Đorđije has expressed a negative side of personality is equated with a dream by the inner psychological self-defense mechanism.

CONCLUDING The linguistic-stylistic approach to Andrićs prose in the context of REMARKS psychological and sociological interpretation of social relations reveals the semantic polyvalence of conceptual layers of his prose, openness of the literary work $(\mathrm{Eco}, 1965)$ and inspires to reflection on many ethical issues. Stylistic expression is utilized for the purpose of inner psychological characterization and brings to light hidden fears and dilemmas of the protagonists. The behavior of child protagonists is shaped by the impact of their community and individual personality traits. Despite temptations, bitter experiences, fears, and disappointments, Andrić's heroes manage to keep their decency and humanity. Conceptual layers of the analyzed short stories prove that in addition to aesthetic, his prose has an ethical role as well, guiding a young reader "to develop love and respect for an individual and humanity as a whole" (Jovanović and Kačapor, 2016, p. 354).

SOURCES Андрић, И. (1963). Дец̧а- йрийовейке. Београд: Просвета.

REFERENCES Абрахам, К. (1999). Сӣиси из йримењене ӣсихоанализе. Сремски Карловци/ Нови Сад: Издавачка књижарница Зорана Стојановића.

Јовановић, Б. и Качапор, С. (2016). Васпитање за међународну толеранцију и сарадњу. Теме XL(1), 351-364.

Маричић, J. (2009). Теорије и истраживања предрасуда у дечјој доби. Психолоіијске йеме 18(1), 137-157.

Марјановић, В. (2009). Поеӣика књижевносӣи за gеиу и млаgе. Београд: КИЗ Центар.

Миливојевић, 3. (1993). Психое̄ераӣија и разумевање емоизја. Нови Сад: Прометеј. 
Милинковић, М. (2014). Исӣорија срӣске књижкевност̄и за gеиу и млаgе. Београд: Bookland.

Сузуки Д. Т. и Фром, Е. (1977). Зен буgизам и йсихоанализа. Београд: Нолит.

Томашић, J. (2011). Теоријска питања и методолошки изазови у истраживањима. Лет̄оӣuс соицијалноі paga 18(36), 601-633.

Чајкановић, В. (1994). С̄̄ара срӣска релиїuја и мийолоїија. Београд: Српска књижевна задруга/БИГз/ Просвета/Партенон.

Allport, G. (1954). The nature of prejudice. Cambridge, MA: Addison-Wesley.

Aronson, E., Wilson, T. D. \& Akert, R. M. (2010). Social psychology (Seventh Edition). Upper Saddle River, NJ: Prentice Hall.

Bajer. V. (1969). Ugovor sa đavolom. Zagreb: Zora.

Dimoski, S. (2011). Stavovi prema osobama oštećenog sluha i faktori koji ih određuju. Beograd: Fakultet za specijalnu edukaciju i rehabilitaciju.

Dimoski, S. (2012). Psihoanalitička tumačenja predrasuda sa osvrtom na predrasude prema osobama sa ometošću. Specijalna edukacija i rehabilitacija 11(4), 605-621.

Eko, U. (1965). Otvoreno delo. Sarajevo: Veselin Masleša.

Frojd, S. (1964). Uvod u psihoanalizu. Beograd: Kosmos.

Gidens, E. (2003). Sociologija. Beograd: Ekonomski fakultet.

Greif, G. (2009). The Auschwitz album. A Curriculum for Higs Schools. Jerusalem: Yad Vashem The International School for Holocaust Studies.

Hofstede, G., Hofstede, G. J. \& Minkov, M. (2010). Cultures and Organizations: Software of the Mind, Intercultural Cooperation and Its Importance for Survival. United States of America: McGraw-Hill Companies.

Jung, K. G. (1984). Dinamika nesvesnog. Novi Sad: Matica srpska.

Milgram, A. (1999). But the story didn't end that way. Jerusalem: Yad Vashem The International School for Holocaust Studies.

Nesdale, D. (1999). Social identity and ethnic prejudice in children. In: P. Martin \& W. Noble (eds.), Psychology and society (pp. 92-110). Brisbane: Australian Academic Press.

Nesdale, D. (2004). Social identity processes and children's ethnic prejudice. In: M. Bennet \& F. Sani (eds.), The development of social self (pp. 219-245). New York: Psychology Press.

Oppenheimer, L., \& Midzic, E. (2011). National identification and in-group/ out-group attitudes with Bosniak and Serbian children in Bosnia. European Journal of Developmental Psychology 8(1), 43-57.

Rejk, B., i Edkok, K. (1978). Vrednosti, stavovi i promena ponašanja. Beograd: Nolit. 
Stakić, M. (2014). The specifics of children's literature in the context of genre classification. Mediterranean Journal of Social Sciences Vol. 5, № 19, 243-252.

Syentmarton, M. (1990). Psihologija duhovnog života. Zagreb: Filozofskoteološki institut.

Svirčev, Ž. (2010). Ah, taj identitet. Beograd: Službeni glasnik.

Tajfel, H., \& Turner, J. (1979). An integrative theory of intergroup conflict. In: W. G. Austin \& S. Worchel (Eds.), The social psychology of intergroup relations (pp. 33-47). Monterey: Brooks-Cole.

Trebješanin, Ž. (2008). Uvod u opštu psihologiju. Beograd: Fakultet za specijalnu edukaciju i rehabilitaciju. 
МИРЈАНА М. СТАКИК

УНИВЕРЗИТЕТ У КРАГУЈЕВЦУ

УЧИТЕљСКИ ФАКУЛТЕТ У УЖИЦУ

АЛЕКСАНДРА В. ЈАНКОВИЋ

ВИСОКА ШКОЛА СТРУКОВНИХ СТУДИЈА ЗА ОБРАЗОВАњЕ

ВАСПИТАЧА ИЗ ГЬИЛАНА СА ПРИВРЕМЕНИМ СЕДИШТЕМ У БУЈАНОВЦУ

РЕЗИМЕ

РЕФЛЕКСИЈА ДРУШТВЕНИХ ОДНОСА У ЈЕЗИКУ

АНДРИЋЕВЕ ПРОЗЕ ЗА ДЕЦУ И МЛАДЕ

У раду, испитујући језик Андрићеве прозе у приповеткама „Деца“, „Кула“ и „Прозор“ које су намењене деци и младима тумачимо друштвене односе који представљају њихов тематски, социолошки, културолошки и историјски контекст. У контексту учења социолошких теорија (социокогнитивне теорије, теорије социјалног идентитета и теорије социјалног учења), са становишта психолингвистичког приступа, испитујемо узроке друштвених предрасуда које представљају основни узрок настајања интерперсоналних и унутрашњих психолошких конфликта главних јунака. Језик посматрамо и као медијум у откривању унутрашње и спољашње карактеризација ликова остварене посредством вербализације унутрашњих и спољашњих сукоба. Друштвене односе и конфликте рефлектоване у језику као естетском, културном и социјалном феномену тумачимо као идејни контекст Андрићеве прозе. Књижевни језик тако постаје медијум који, поред естетске, остварује и сазнајну улогу откривајући друштвене односе и конфликте који представљају рефлексивно језгро уткано у тематску структуру испитиваних приповедака за децу и младе: „Деца“, „Кула“ и „Прозор“.

КљУчнЕ РЕчИ: КњИжевни језик, психолингвистички приступ, Андрићева проза за децу и младе, друштвени односи, конфликти.

Овај чланак је објављен и дистрибуира се под лиценцом Creative Commons Ауторство-Некомерцијално Међународна 4.0 (СC BY-NC 4.0

https://creativecommons.org/licenses/by-nc/4.0/).

This paper is published and distributed under the terms and conditions of the Creative Commons Attribution-NonCommercial International 4.0 licence (CC BY-NC 4.0 | https://creativecommons.org/licenses/by-nc/4.0/). 